\title{
Optimization of L-asparaginase production by Serratia marcescens (NCIM 2919) under solid state fermentation using coconut oil cake
}

\author{
Sangita Ghosh, Sonam Murthy, Sharmila Govindasamy and Muthukumaran Chandrasekaran*
}

\begin{abstract}
Background: The present study focused on utilization of agrowaste byproducts generated from oil mill for L-asparaginase enzyme production using Serratia marcescens under solid state fermentation. Classical and statistical methods were employed to optimize the process variables and the results were compared.

Results: The classical one factor at a time (OFAT) and response surface methodology (RSM) are employed to optimize the fermentation process. When used as the sole carbon source in SSF, coconut oil cake (COC) showed maximum enzyme production. The optimal values of substrate amount, initial moisture content, $\mathrm{pH}$ and temperature were found to be $6 \mathrm{~g}, 40 \%, 6$ and $35^{\circ} \mathrm{C}$ respectively under classical optimization method with maximum enzyme activity of $3.87\left(\mathrm{U} \mathrm{gds}^{-1}\right)$. Maximum enzyme activity of $5.86 \mathrm{U} \mathrm{gds}^{-1}$ was obtained at the predicted optimal conditions of substrate amount $7.6 \mathrm{~g}$ of COC, initial moisture content of substrate $50 \%$, temperature $35.5^{\circ} \mathrm{C}$ and $\mathrm{pH}$ 7.4. Validation results proved that a good relation existed between the experimental and the predicted model.
\end{abstract}

Conclusions: RSM optimization approach enhances the enzyme production to 33\% when compared to classical method. Utilization of coconut oil cake as a low cost substrate in SSF for L-asparaginase production makes the process economical and also reduces the environmental pollution by converting the oil mill solid waste into a useful bioproduct.

Keywords: Coconut oil cake, L-asparaginase, Serratia marcescens, Response surface methodology

\section{Background}

In recent years, utilization of agriculture based products and byproducts gains more importance in bioprocess industries because of high nutrient content and low cost. Agro byproducts such as oil cakes, peels of banana and citrus, apple pomace, jackfruit seed, wheat and rice bran, baggase have been reported in the literature for production of value added products. Transforming the waste byproducts to a useful bioproduct by fermentation not only reduces the process cost but also the risk of environmental pollution. Coconut oil cake (COC) is obtained as a waste byproduct after oil extraction from dried coconut. Generally COC is used as poultry and fish feed since it is rich in soluble sugars, soluble proteins and

\footnotetext{
* Correspondence: biopearl1981@gmail.com

Bioprocess Laboratory, Department of Biotechnology, School of

Bioengineering, SRM University, Kattankulathur 603203, Chennai, Tamilnadu,
} India

lipids [1]. COC consists of large amount of short chain saturated fatty acids, crude protein $(25.2 \%)$, crude fibre (10.8\%), ash content (6\%), phosphorus $(0.67 \%)$ and calcium $(0.08 \%)$ [2]. COC has been successfully utilized as a potential substrate in SSF for production of biomolecules, particularly enzymes $[1,3-6]$.

L-asparaginase (EC.3.5.1.1) is a key enzyme mainly responsible for the hydrolysis of L-asparagine to L-aspartate and ammonia. In recent years, it has received importance for the treatment of various diseases like acute myelocytic leukemia, acute myelomonocytic leukemia, chronic lymphocytic leukemia and acute lymphoblastic leukemia [7-9]. L-asparaginase is present in a wide range of organisms including animals, microbes and plants. Microbial production of L-asparaginase has attracted more attention because of cost-effective and eco-friendly process. A wide range of microorganisms such as filamentous fungi $[10,11]$, bacteria [12-14], yeast $[15,16]$ and actinomycetes 
[17] have been reported in the literature for production of this enzyme. L-asparaginase production has been widely carried out by submerged fermentation (SmF) process. Though, SmF process is well established, it possesses few disadvantages like huge volume of waste water generation and difficulties in effluent treatment process [18]. Because of the above disadvantages, Solid state fermentation (SSF) has emerged as an alternate cost- effective process for bioproducts production by utilizing the agrowastes and byproducts [19]. It has been employed for production of various microbial metabolites such as enzymes [3,4,20], organic acids [21-23] and antibiotics [24,25]. Optimization of bioprocess by one factor at a time (OFAT) is a wellstudied method but it has some disadvantages like more time consumption, more number of experimental runs and lack of knowledge about the interaction between the variables involved in the process [26]. Use of statistical experimental designs for screening and optimization of the process variables or conditions is well suited to study the interactive effects of the variables on the targeted response $[10,13,27]$. The main objective of this study was to produce L-asparaginase by selecting an appropriate low cost substrate and to determine the optimal level of the process variables by both OFAT and RSM methods.

\section{Experimental}

\section{Microorganism and media}

Bacterial strain Serratia marcescens (NCIM 2919) was procured from the National Collection of Industrial Microorganisms, National Chemical Laboratory, Pune, India. The stock culture was maintained at $37^{\circ} \mathrm{C}$ on Luria Bertani (LB) agar slants. Inoculum was prepared by adding a loopful of bacterial colonies in $500 \mathrm{~mL}$ Erlenmeyer flasks containing $100 \mathrm{~mL}$ of LB broth and incubated in a rotary shaker at $37^{\circ} \mathrm{C}$ for $24 \mathrm{~h}$.

\section{Screening of substrates}

Three natural substrates Coconut oil cake (COC), Cottonseed oil cake (CSOC) and Groundnut oil cake (GOC) used in this study were purchased from the local market in Chennai. $2 \mathrm{~mL}$ of overnight grown culture was inoculated into the Erlenmeyer flask containing $10 \mathrm{~g}$ of the respective substrate. The flasks were incubated at $37^{\circ} \mathrm{C}$ in temperature - controlled incubator and the contents mixed at regular intervals. Fermented samples were taken at $24 \mathrm{~h}$ intervals and assayed for enzyme activity.

\section{Analytical methods}

Enzyme extraction and assay Extraction of crude enzyme was done by adding $100 \mathrm{~mL}$ of sodium phosphate buffer ( $\mathrm{pH} \mathrm{7)}$ to the fermented substrate, and kept in rotator shaker for $45 \mathrm{~min}$. One milliliter of the extract was transferred to the eppendorf tube and centrifuged at $10000 \mathrm{rpm}$ for 10 minutes. L-asparaginase activity was determined by measuring the amount of ammonia released by nesslerization according to the method described by Wriston and Yellin [28]. $0.2 \mathrm{~mL}$ of cell free supernatant was mixed with $0.8 \mathrm{~mL}$ of $0.1 \mathrm{M}$ sodium borate buffer $(\mathrm{pH} 8.5)$ and $1 \mathrm{~mL}$ of $0.04 \mathrm{M} \mathrm{L}$-asparagine and incubated for $10 \mathrm{~min}$. $0.5 \mathrm{~mL}$ of $15 \%$ TCA was added to stop the reaction and again centrifuged for $10000 \mathrm{rpm}$ for 10 minutes. $0.2 \mathrm{~mL}$ of the supernatant was taken in a test tube in which $3.6 \mathrm{~mL}$ distilled water and $0.2 \mathrm{~mL}$ Nessler's reagent were added. The optical density was measured at $480 \mathrm{~nm}$ in UV spectrophotometer. One Unit $(U)$ of L-asparaginase is defined as the amount of enzyme required to liberate one $\mu \mathrm{mol}$ of ammonia per min at $37^{\circ} \mathrm{C}$.

\section{Optimization studies}

Classical optimization The optimization process was carried out by one factor at a time (OFAT) method by varying only a single factor and keeping the remaining factors constant. The optimal level of substrate was studied by varying the amount $(2 \mathrm{~g}, 4 \mathrm{~g}, 6 \mathrm{~g}, 8 \mathrm{~g}$, and $10 \mathrm{~g})$. The initial moisture content was varied over the range of $30 \%, 40 \%, 50 \% .60 \%$ and $70 \%$. Optimum $\mathrm{pH}$ and temperature were determined by studying a range of 6 to 8 and 25 to $45^{\circ} \mathrm{C}$ respectively, while all other factors were kept constant. Samples were drawn continuously at $24 \mathrm{~h}$ interval and the enzyme assay was carried out to calculate the enzyme activity.

\section{Statistical optimization}

Response Surface Methodology (RSM) was employed to identify the optimized conditions for the enzyme production. Box-Behnken Design [29] of RSM was used to design the experiment using Design Expert software. Four process variables namely substrate amount (A), initial moisture content (B), temperature (C) and $\mathrm{pH}(\mathrm{D})$ were studied at three levels $(+1,0,-1)$ and the experimental range is given in Table 1 . Twenty nine experiments were carried out according to Table 1 and the enzyme activity was calculated after $96 \mathrm{~h}$ of incubation. A second order polynomial model which describes the relation between the response and the chosen variables was developed and given in Eqn 1.

$$
Y=\alpha_{0}+\sum_{j=1}^{k} \alpha_{j} X_{j}+\sum_{j=1}^{k} \alpha_{j j} X_{j}^{2}+\sum \sum \alpha_{i j} X_{i} X_{j}
$$

where $Y$ is the response, $\alpha_{0}, \alpha_{j}, \alpha_{j j}, \alpha_{i j}$ are the regression coefficients for the intercept, linear, quadratic and interaction effects, respectively and $X_{i}$ and $X_{j}$ are coded independent variables. 
Table 1 Experimental range and level of the process variables for $L$-asparaginase production

\begin{tabular}{lcccc}
\hline Process variables & Symbol & Low (-1) & Middle (0) & High (+1) \\
\hline Amount of substrate $(\mathrm{g})$ & $\mathrm{A}$ & 4 & 6 & 8 \\
$\begin{array}{l}\text { Initial moisture } \\
\text { content }(\%)\end{array}$ & $\mathrm{B}$ & 30 & 40 & 50 \\
Temperature $\left({ }^{\circ} \mathrm{C}\right)$ & $\mathrm{C}$ & 30 & 35 & 40 \\
$\mathrm{pH}$ & $\mathrm{D}$ & 6 & 7 & 8 \\
\hline
\end{tabular}

\section{Results and discussion}

\section{Screening of carbon substrate}

In SSF process, the selection of appropriate substrate should be based on nutrient value, availability and cost. The solid substrate not only provides nutrients for growth and metabolic activities but also provides anchorage to microbes for growth.

A series of experiments were carried out by using Coconut oil cake (COC), Cottonseed oil cake (CSOC) and Groundnut oil cake (GOC) as carbon source for Lasparaginase production by Serratia marcescens. The experimental results for screening of carbon source is graphically shown in Figure 1. All the four substrates showed positive results for the production of the enzyme with yields varying in the range of 0.6 to 3.70 (U/gds) (Figure 1). COC showed maximum enzyme activity of 3.79 (U/gds) as compared to CSOC and GOC. In our study coconut oil cake (GOC) showed better results than the other solid substrates. As a waste product of oil industries, the use of GOC as a carbon source may reduce the cost of the enzyme production process.
Effect of carbon source on L-asparaginase production

The amount of substrate also plays a vital role for the enhancement of the enzyme production. Five different initial substrate (COC) amounts ( $2 \mathrm{~g}, 4 \mathrm{~g}, 6 \mathrm{~g}, 8 \mathrm{~g}$ and $10 \mathrm{~g})$ were considered for optimization studies. Figure $2 \mathrm{~A}$ shows a constant increase in enzyme activity with a maximum value of 3.12 (U/gds) for $6 \mathrm{~g}$ of substrate. The optimum substrate amount is mainly required for growth and production of metabolites by microorganisms in SSF. High and low levels of the substrate may be leads to decrease the yield of the process. Reduction in the enzyme yield may be due to substrate inhibition when substrate used in high level whereas low level of substrate may decrease the yield because of less nutrient availability for microbial growth and metabolite synthesis. Thus, a optimal amount of substrate should be used for the better results and $6 \mathrm{~g}$ of COC was found optimum substrate amount for Lasparaginase production in our study.

\section{Effect of initial moisture content on L-asparaginase production}

Initial moisture content is a very important parameter in solid state fermentation and directly affects the enzyme production and its activity. Five different moisture contents were taken into account i.e. 30\%, 40\%, 50\%, $60 \%$ and $70 \%$. Figure $2 \mathrm{~B}$ shows that maximum activity of 3.49 (U/gds) was attained with $40 \%$ initial moisture content after $96 \mathrm{~h}$ of incubation. In this study,decrease in enzyme activity was observed at low and high level of moisture content. This can be attributed to the fact that higher moisture level decreases porosity, promotes

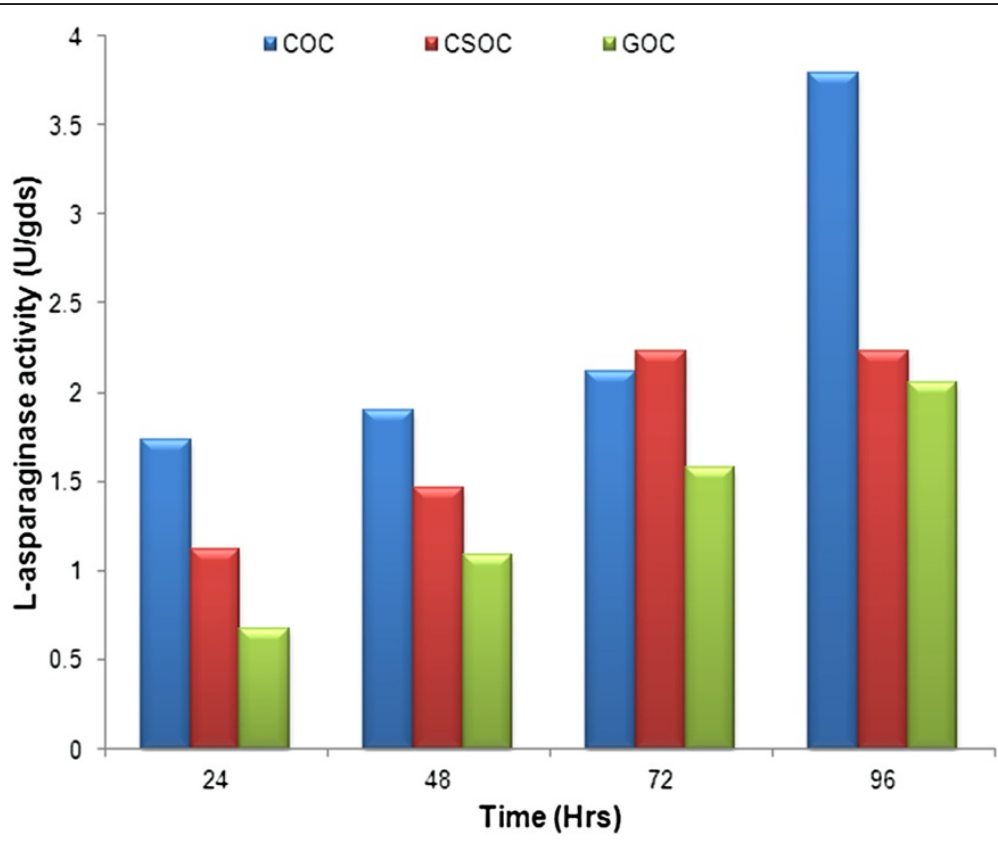

Figure 1 Graph showing time course profile of L-asparaginase production in $\mathrm{COC}$, CSOC and GOC substrates. 

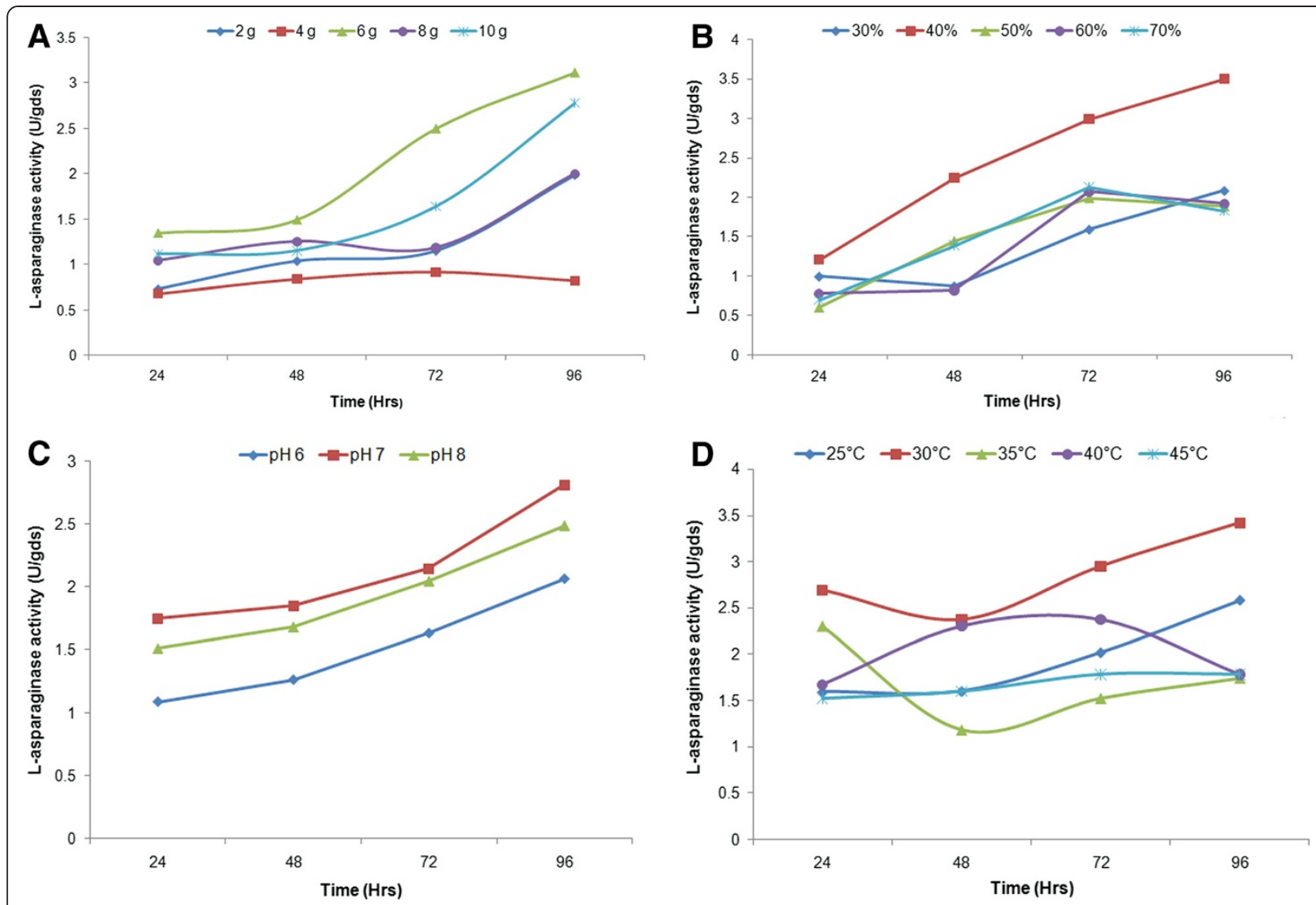

Figure 2 Graph showing the effect of factors on L-asparaginase activity A: amount of substrate, B: initial moisture content, C: $\mathrm{pH}$ and D: temperature.

development of stickiness, and increases the chances of contamination [30].

\section{Effect of $\mathrm{pH}$ on L-asparaginase production}

The $\mathrm{pH}$ of the extraction buffer of the enzyme is yet another important factor. Buffers with $\mathrm{pH}$ of 6,7 and 8 were taken into observation. Highest enzyme activity of 2.81 (U/gds) was recorded at a $\mathrm{pH}$ of 7 after $96 \mathrm{~h}$ of incubation. Figure $2 \mathrm{C}$ shows the enzyme activity for the various $\mathrm{pH}$ conditions. L-asparaginase from Serratia marcerens showed high stability and maximum activity at neutral $\mathrm{pH}$ in our study. Maximum enzyme activity was observed near neutral $\mathrm{pH}$ for the strain Serratia marcerens whereas the optimum $\mathrm{pH}$ value was varied for different strains employed in L-asparaginase production E.coli (pH 9) and Pseudomonas aeruginosa (pH 8) [26,31].

\section{Effect of incubation temperature on L-asparaginase production}

The incubation temperature has a direct effect on the growth of the bacteria and thus affects the enzyme production and its activity. A range of temperature varying from $25^{\circ} \mathrm{C}$ to $45^{\circ} \mathrm{C}$ was taken into study. Maximum enzyme activity of 3.42 (U/gds) was recorded at $30^{\circ} \mathrm{C}$ after $96 \mathrm{~h}$ of incubation as represented in Figure 2D. Further increase in the temperature resulted in reduction of enzyme activity. An experiment was carried out at the optimum values of substrate amount $(6 \mathrm{~g})$, initial moisture content $(40 \%), \mathrm{pH}(7)$ and temperature $\left(30^{\circ} \mathrm{C}\right)$ obtained from OFAT method and maximum enzyme activity ( $3.87 \mathrm{U} / \mathrm{gds}$ ) was found after $96 \mathrm{~h}$ of fermentation. In this study, Serratia marcerens strain showed maximum enzyme activity at optimum temperature of $30^{\circ} \mathrm{C}$. The optimum temperature for enzyme production varies with bacterial strains. Maximum enzyme activity was expected at $20^{\circ} \mathrm{C}$ for Chrombacteriaceae [32] and optimum temperature of $37^{\circ} \mathrm{C}$ was reported for various bacterial species $[8,33,34]$.

\section{Optimization of process parameters using response surface methodology}

Response surface methodology is one of the statistical techniques to evaluate the relationship between the experimental variables and the measured responses and 
to find the optimal range of the process variables within the design [35]. In our study, we used BoxBehnken design to determine the optimal level of the four variables which influences the enzyme production. The response, L-asparaginase activity ranged from 2.82 (U/gds) to 6.18 (U/gds) as tabulated in Table 2. Analysis of Variance (ANOVA) was performed to obtain the interaction between the process variables and the response. ANOVA statistics results and the estimated regression coefficients are given in Table 3. A second order polynomial equation given in Eqn. 2 was constructed by using the estimated coefficients (in coded units).

Table 2 Box-Benhken Design matrix with experimental and predicted L-asparaginase activity

\begin{tabular}{|c|c|c|c|c|c|c|}
\hline \multirow{2}{*}{$\begin{array}{l}\text { Std } \\
\text { order }\end{array}$} & \multirow[t]{2}{*}{ A } & \multirow[t]{2}{*}{ B } & \multirow[t]{2}{*}{ C } & \multirow[t]{2}{*}{ D } & \multicolumn{2}{|c|}{ L-asparaginase activity (U/gds) } \\
\hline & & & & & Experimental & Predicted \\
\hline 1 & 4 & 30 & 35 & 7 & 4.710 & 4.688 \\
\hline 2 & 8 & 30 & 35 & 7 & 4.655 & 4.860 \\
\hline 3 & 4 & 50 & 35 & 7 & 2.912 & 3.729 \\
\hline 4 & 8 & 50 & 35 & 7 & 4.790 & 5.829 \\
\hline 5 & 6 & 40 & 30 & 6 & 3.458 & 3.802 \\
\hline 6 & 6 & 40 & 40 & 6 & 3.493 & 3.647 \\
\hline 7 & 6 & 40 & 30 & 8 & 3.352 & 4.220 \\
\hline 8 & 6 & 40 & 40 & 8 & 3.534 & 4.212 \\
\hline 9 & 4 & 40 & 35 & 6 & 3.827 & 3.279 \\
\hline 10 & 8 & 40 & 35 & 6 & 3.504 & 3.512 \\
\hline 11 & 4 & 40 & 35 & 8 & 3.305 & 2.866 \\
\hline 12 & 8 & 40 & 35 & 8 & 4.790 & 4.907 \\
\hline 13 & 6 & 30 & 30 & 7 & 5.354 & 4.922 \\
\hline 14 & 6 & 50 & 30 & 7 & 6.182 & 5.370 \\
\hline 15 & 6 & 30 & 40 & 7 & 4.902 & 5.284 \\
\hline 16 & 6 & 50 & 40 & 7 & 4.843 & 4.846 \\
\hline 17 & 4 & 40 & 30 & 7 & 3.264 & 3.813 \\
\hline 18 & 8 & 40 & 30 & 7 & 4.338 & 4.058 \\
\hline 19 & 4 & 40 & 40 & 7 & 2.823 & 2.840 \\
\hline 20 & 8 & 40 & 40 & 7 & 5.683 & 4.869 \\
\hline 21 & 6 & 30 & 35 & 6 & 4.174 & 4.579 \\
\hline 22 & 6 & 50 & 35 & 6 & 4.679 & 4.634 \\
\hline 23 & 6 & 30 & 35 & 8 & 5.342 & 5.120 \\
\hline 24 & 6 & 50 & 35 & 8 & 5.747 & 5.075 \\
\hline 25 & 6 & 40 & 35 & 7 & 5.858 & 5.169 \\
\hline 26 & 6 & 40 & 35 & 7 & 5.013 & 5.169 \\
\hline 27 & 6 & 40 & 35 & 7 & 4.802 & 5.169 \\
\hline 28 & 6 & 40 & 35 & 7 & 4.855 & 5.169 \\
\hline 29 & 6 & 40 & 35 & 7 & 5.049 & 5.169 \\
\hline
\end{tabular}

Table 3 ANOVA statistics for L-asparaginase production by Serratia marcescens

\begin{tabular}{|c|c|c|c|c|c|c|}
\hline Source & $\begin{array}{l}\text { Sum of } \\
\text { squares }\end{array}$ & $\begin{array}{c}\text { Degrees of } \\
\text { freedom }\end{array}$ & $\begin{array}{c}\text { Mean } \\
\text { square }\end{array}$ & $\begin{array}{c}F \\
\text { value }\end{array}$ & $\begin{array}{c}\mathrm{p}- \\
\text { value }\end{array}$ & Significance \\
\hline A & 3.989 & 1 & 3.989 & 7.966 & 0.014 & significant \\
\hline B & 2.130 & 1 & 2.130 & 4.260 & 0.995 & \\
\hline C & 0.037 & 1 & 0.037 & 0.074 & 0.789 & \\
\hline D & 0.717 & 1 & 0.717 & 1.433 & 0.251 & \\
\hline$A B$ & 0.934 & 1 & 0.934 & 1.865 & 0.193 & \\
\hline$A C$ & 0.797 & 1 & 0.797 & 1.592 & 0.228 & \\
\hline$A D$ & 0.817 & 1 & 0.817 & 1.631 & 0.222 & \\
\hline$B C$ & 0.196 & 1 & 0.196 & 0.392 & 0.541 & \\
\hline$B D$ & 0.002 & 1 & 0.002 & 0.004 & 0.945 & \\
\hline$C D$ & 0.005 & 1 & 0.005 & 0.010 & 0.919 & \\
\hline$A^{2}$ & 4.169 & 1 & 4.169 & 8.326 & 0.012 & significant \\
\hline$B^{2}$ & 1.086 & 1 & 1.086 & 2.170 & 0.162 & \\
\hline$c^{2}$ & 1.455 & 1 & 1.455 & 2.906 & 0.110 & \\
\hline$D^{2}$ & 3.421 & 1 & 3.421 & 6.832 & 0.020 & significant \\
\hline Residual & 7.010 & 14 & 0.500 & & & \\
\hline $\begin{array}{c}\text { Lack of } \\
\text { Fit }\end{array}$ & 6.278 & 10 & 0.627 & 3.429 & 0.123 & $\begin{array}{c}\text { not } \\
\text { significant }\end{array}$ \\
\hline $\begin{array}{l}\text { Pure } \\
\text { Error }\end{array}$ & 0.732 & 4 & 0.183 & & & \\
\hline Total & 24.558 & 28 & & & & \\
\hline \multicolumn{7}{|c|}{$\begin{array}{c}\mathrm{Y}_{L-\text { asparaginase activity }(U / g d s)}=5.12+0.58^{*} \mathrm{~A}+1.33 \mathrm{E} \\
-003^{*} \mathrm{~B}-0.056^{*} \mathrm{C}+0.24^{*} \mathrm{D}+0.48^{*} \mathrm{AB} \\
+0.45^{*} \mathrm{AC}+0.45^{*} \mathrm{AD}-0.22^{*} \mathrm{BC} \\
-0.025^{*} \mathrm{BD}+0.037^{*} \mathrm{CD}-0.80^{*} \mathrm{~A}^{2} \\
+0.41^{*} \mathrm{~B}^{2}+0.47^{*} \mathrm{C}^{2}-0.73^{*} \mathrm{D}^{2}\end{array}$} \\
\hline
\end{tabular}

The probability value ( $\mathrm{p}$-value) is usually used to evaluate the statistical significance of each coefficient [29]. Low $\mathrm{p}$-value $(\mathrm{p}<0.05)$ indicates high significance of the corresponding coefficient and its effect on the Lasparaginase activity at $95 \%$ confidence level. The statistical significance of the model equation was evaluated by the $F$-test of ANOVA table. The model was found highly significant with the F-value of 2.50. From Table 3 , the linear effect of substrate (COC) amount (A) and the square effect of substrate (COC) amount (A) and $\mathrm{pH}$ (D) were found to be more significant $(\mathrm{p}<0.05)$ than the other linear and interaction effects between process variables. The correlation coefficient $\left(R^{2}\right)$ is a tool to check the "goodness of fit" of the polynomial model and $\mathrm{R}^{2}$ value near to unity is said to be perfect fit. In this study, $R^{2}$ value of 0.714 demonstrated that there was 
good relation existed between the independent and the dependent variables.

\section{Surface plots}

The contour and 3D surface plots are generally used to represent the interaction effects between the process variables [36]. The fitted response for the regression model was plotted in Figure 3A-F. 3D graphs generated for the pair-wise interaction of the four factors explain the role played by factors affecting L-asparaginase production. The three dimensional response surface plot between the amount of substrate and the initial moisture content (Figure 3A) shows that the enzyme activity increased towards the high value of the substrate amount and reached a maximum (4.60 U/gds) in the mid-value region whereas, in case of the initial moisture content, a

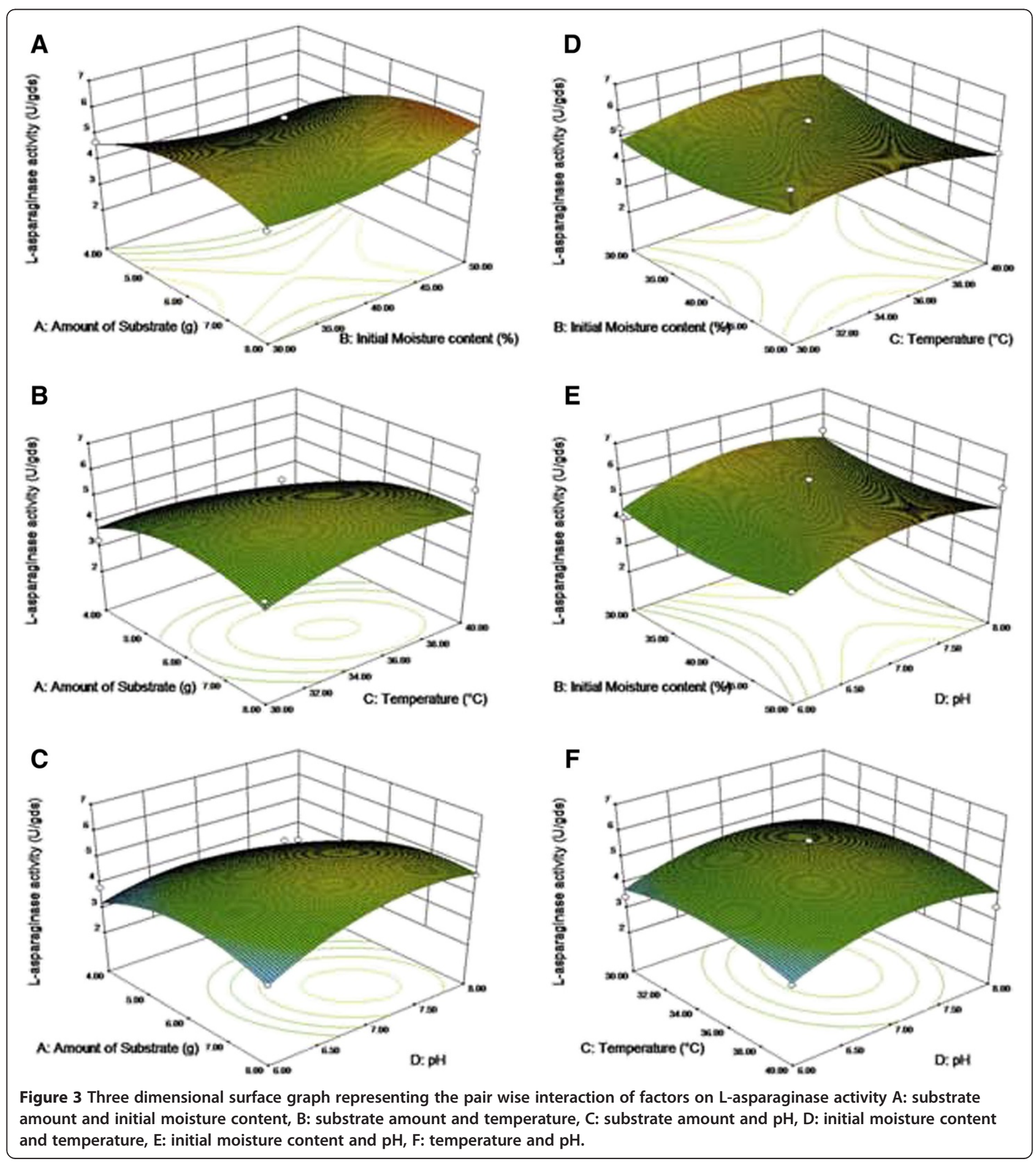


maximum of enzyme activity (5.80 U/gds) was observed at the high value of moisture content (50\%). Figure 3B represents the combined effect of the substrate amount and temperature and maximum activity (3.90 U/gds) was noted at the mid value of substrate amount $(6 \mathrm{~g})$. The activity steadily increased with the increase in temperature and reached a maximum $(4.90 \mathrm{U} / \mathrm{gds})$ at the optimal value of temperature $\left(50^{\circ} \mathrm{C}\right)$. The interaction between the substrate amount and $\mathrm{pH}$ (Figure 3C) showed that while mid value of substrate continued to give the maximum activity, high level of the $\mathrm{pH} 8$ was seen to increase the activity to a maximum (4.95 U/gds). The response plot between the initial moisture content and temperature (Figure 3D) demonstrates that the activity was almost constant for the initial moisture content values with slightly high activity recorded for the low value. It remained constant for the temperature variations. The graph between initial moisture content and $\mathrm{pH}$ (Figure 3E) highlights a constant activity for the initial moisture content whereas a maximum activity (4.99 U/gds) was recorded for the high level of $\mathrm{pH}$. The interaction plot between the temperature and $\mathrm{pH}$ (Figure 3F) implies that the enzyme activity remained constant for the temperature variations whereas in case of $\mathrm{pH}$, there was an increase and a maximum activity (4.00 U/gds) was recorded at the high level. According to Muralidhar et al. [37], strong interaction between the variables are expected if the contour lines are elliptical in shape. In our study, strong interaction existed between the amount of substrate and temperature (Figure 3B), amount of substrate and $\mathrm{pH}$ (Figure $3 \mathrm{C}$ ) and temperature and $\mathrm{pH}$ (Figure $3 \mathrm{~F}$ ) for L-asparaginase production since the contour lines were elliptical in nature.

\section{Response optimization}

Point Prediction tool of Design Expert software was used to predict the optimum values of the variables. Maximum enzyme activity (5.86 U/gds) was obtained at the predicted optimal values of substrate amount $7.6 \mathrm{~g}$, Initial moisture content of substrate $50 \%$, Temperature $35.5^{\circ} \mathrm{C}$ and $\mathrm{pH}$ 7.4.

\section{Validation of model}

An experiment was carried out with the optimum values predicted by the software to verify the accuracy of the model. Validation results showed that experimental value of enzyme activity ( $5.75 \mathrm{U} / \mathrm{gds})$ was very closer to the predicted response $(5.86 \mathrm{U} / \mathrm{gds})$ and the predicted model fitted well with $97.4 \%$ of experimental results. Our study showed significant results for L-asparaginase production by Serratia marcescens in SSF, since there was no previous literature available for the enzyme production by using COC and Serratia marcescens.

\section{Conclusion}

Response surface methodlogy was successfully employed to optimize the process variables for L-asparaginase production. Four variables (substrate amount, Initial moisture content of substrate, Temperature and $\mathrm{pH}$ ) were chosen for optimization studies by RSM. Under optimal conditions, L-asparaginase activity of $5.75 \mathrm{U} / \mathrm{gds}$ was obtained and it is closer to the predicted value. Application of RSM for optimization studies is an effective method for improving the enzyme production and also understanding the interaction effects between the variables with less number of experiments. The results of this study also revealed that utilization of coconut oil cake might be reduced the cost of therapeutically important L-asparaginase enzyme production.

\section{Abbreviations}

SSF: Solid state fermentation; COC: Coconut oil cake; CSOC: Cottonseed oil cake; GOC: Groundnut oil cake; GDS: Gram dry substrate; OFAT: One factor at a time; RSM: Response Surface Methodology; BBD: Box-Behnken Design; ANOVA: Analysis of variance; $p$ : Probalility value.

\section{Competing interests}

The authors declared that they have no competing interests.

\section{Authors' contribution}

SG \& SM carried out the experimental work. GS \& CM designed the study and involved in all discussions, data interpretation and manuscript drafting. All authors read and approved the final manuscript.

\section{Acknowledgement}

Authors are acknowledging with thanks to the Management of SRM University, Director (E\&T) for supporting the research and also thank the Department of Biotechnology for providing the facilities to carry out this study.

Received: 13 March 2013 Accepted: 14 June 2013

Published: 5 July 2013

\section{References}

1. Ramachandran S, Patel AK, Nampoothiri KM, Francis F, Nagy V, Szakacs G, Pandey A: Coconut oil cake - a potential raw material for the production of a-amylase. Bioresour Technol 2004, 93:169-174.

2. Ramachandran S, Singh SK, Larroche C, Soccol CR, Pandey A: Oil cakes and their biotechnological applications - A review. Bioresour Technol 2007, 98:2000-2009.

3. Sandhya C, Sumantha A, Szakacs G, Pandey A: Comparative evaluation of neutral protease production by Aspergillus oryzae in submerged and solid-state fermentation. Process Biochem 2005, 40:2689-2694.

4. Bogar B, Szakacs G, Pandey A, Sabu A, Linden JC, Tengerdy RP: Production of phytase by Mucor racemosus in solid-state fermentation. Biotechnol Progr 2003, 19:312-319.

5. Benjamin S, Pandey A: Coconut cake: a potent substrate for production of lipase by Candida rugosa in solid-state fermentation. Acta Biotechnol 1997, 17:241-251.

6. Selvakumar P, Pandey A: Solid-state fermentation for the synthesis of inulinase from Staphylococcus sp. and Kluyveromyces marxianus. Process Biochem 1999, 34:851-855.

7. Umesh K, Shamsher S, Wamik A: Pharmacological and clinical evaluation of L-asparaginase in the treatment of Leukemia. Crit Rev Oncol Hematol 2007, 61:208-221.

8. Manna S, Sinha A, Sadhukhan R, Chakrabarty SL: Purification, characterization and antitumor activity of L-asparaginase isolated from Pseudomonas stutzeri MB-405. Curr Microbiol 1995, 30:291-298.

9. Adamson $\mathrm{RH}$, Fabro S: Antitumor activity and other biologic properties of L-asparaginase. Cancer Chemother Rep 1968, 52:617-626. 
10. Baskar G, Renganathan S: Design of experiments and artificial neural network linked genetic algorithm for modeling and optimization of Lasparaginase production by Aspergillus terreus MTCC 1782. Biotechnol Bioprocess Eng 2011, 16:50-58.

11. Mishra A: Production of L-asparaginase, an anticancer agent, from Aspergillus niger using agricultural waste in solid state fermentation. Appl Biochem Biotechnol 2006, 135:3-42.

12. Kumar S, Dasu W, Pakshirajan K: Localization and production of novel Lasparaginase from Pectobacterium carotovorum MTCC 1428. Process Biochem 2010, 45:223-229.

13. Seyedeh LDK, Iran A, Vida M: Production of L- asparaginase from Escherichia coli ATCC 11303: Optimization by response surface methodology. Food Bioprod Process 2011, 89:315-321.

14. Heinemann B, Howard AJ: Production of tumor-inhibitory L-asparaginase by submerged growth of Serratia marcescens. Appl Microbiol 1969, 18:550-554.

15. Kil JO, Kim GN, Park I: Extraction of extracellular L-asparaginase from Candida utilis. Biosci Biotechnol Biochem 1995, 59:749-750.

16. Ramakrishnan MS, Joseph R: Characterization of an extracellular asparaginase of Rhodosporidium toruloides CBS14 exhibiting unique physicochemical properties. Can J Microbiol 1996, 42:316-325.

17. Saleem Basha N, Rekha R, Komala M, Ruby S: Production of extracellular anti-leukaemic enzyme L-asparaginase from marine Actinomycetes by solid state and submerged fermentation: Purification and Characterization. Trop J Pharm Res 2009, 8:353-360.

18. Datar R: Economics of primary separation steps in relation to fermentation and genetic engineering. Process Biochem 1986, 21:19-26.

19. Pandey A, Selvakumar P, Soccol CR, Nigam P: Solid state fermentation for the production of industrial enzymes. Curr Sci 1999, 77:149-162.

20. El-Bessoumy AA, Sarhan M, Mansour J: Production, isolation and purification of L-asparaginase from Pseudomonas aeruginosa 50071 using solid state fermentation. J Biochem Mol Biol 2004, 37:387-393.

21. Rojan P, John K, Nampoothiri M, Pandey A: Solid-state fermentation for Llactic acid production from agro wastes using Lactobacillus delbrueckii. Process Biochem 2006, 41:759-763.

22. Corona A, Sa'ez D, Agosin E: Effect of water activity on gibberellic acid production by Gibberella fujikuroi under solid-state fermentation conditions. Process Biochem 2005, 40:2655-2658.

23. Vandenberghe LPS, Soccol CR, Pandey A, Lebeault JM: Solid-state fermentation for the synthesis of citric acid by Aspergillus niger. Bioresour Technol 2000, 74:175-178.

24. Sarada I, Sridhar P: Nutritional improvement for Cephamycin C fermentation using a superior strain of Streptomyces clavuligerus. Process Biochem 1998, 33:317-322.

25. Sircar A, Sridhar P, Das PK: Optimization of solid state medium for the production of clavulanic acid by Streptomyces clavuligerus. Process Biochem 1998, 33:283-289.

26. Abdel-Fattah YR, Olama ZA: L-asparaginase production by Pseudomonas aeruginosa in solid-state culture: Evaluation and optimization of culture conditions using factorial designs. Process Biochem 2002, 38:115-122.

27. Sharmila G, Nidhi B, Muthukumaran C: Sequential statistical optimization of red pigment production by Monascus purpureus (MTCC 369) using potato powder. Ind Crop Prod 2013, 44:158-164.

28. Wriston JC, Yellin TO: L-asparaginase: a review. Adv Enzymol Relat Areas Mol Biol 1973, 39:185-248.

29. Box GEP, Behnken DW: Some new three level designs for the study of quantitative variables. Technometrics 1960, 2:455-475.

30. Lonsane BK, Ghildyal NP, Budiatman S, Ramakrishna SV: Engineering aspects of solid-state fermentation. Enzyme Microb Technol 1985 7:258-265.

31. Liboshi Y, Papst PJ, Hunger SP, Terada N: L-asparaginase inhibits the rapamycine-targeted signaling pathway. Biochem Biophys Res Commun 1999, 260:534-539.

32. Roberts J, Holcenberg IS, Dolwy WC: Crystallization and properties of Achromobacteriacae glutaminase, asparaginase with antitumor activity. J Biol Chem 1972, 247:84-90.

33. Sobis M, Mikucki J: Staphylococcal L-asparaginase: Enzyme kinetics. Acta Microbiol Pol 1991, 40:143-152.

34. Maladkar NK, Singh VK, Naik SR: Fermentative production and isolation of L-asparaginase from Erwinia cartovora EC-113. Hindustan Antibiot Bull 1993, 35:77-86.
35. Myers RH, Montgomery DC: Response surface methodology: Process and product optimization using designed experiments. New York: John Wiley \& Sons; 1995.

36. Bas $D$, Boyaci $H$ : Modeling and optimization I: Usability of response surface methodology. J Food Eng 2007, 78:836-845.

37. Muralidhar RV, Chirumamila RR, Marchant R, Nigam P: A response surface approach for the comparison of lipase production by Candida cylindracea using two different carbon sources. Biochem Eng J 2001, 9:17-23.

doi:10.1186/2043-7129-1-9

Cite this article as: Ghosh et al:: Optimization of L-asparaginase production by Serratia marcescens (NCIM 2919) under solid state fermentation using coconut oil cake. Sustainable Chemical Processes 2013 1:9.

Publish with ChemistryCentral and every
scientist can read your work free of charge
"Open access provides opportunities to our
colleagues in other parts of the globe, by allowing
anyone to view the content free of charge."
W. Jeffery Hurst, The Hershey Company.
- available free of charge to the entire scientific community
- peer reviewed and published immediately upon acceptance
- cited in PubMed and archived on PubMed Central
- yours - you keep the copyright
submit your manuscript here:
http://www.chemistrycentral.com/manuscript/

